\title{
Teaching Evidence-Based Management in MBA Programs: What Evidence Is There?
}

\author{
STEVEN D. CHARLIER \\ KENNETH G. BROWN \\ SARA L. RYNES \\ University of Iowa
}

\begin{abstract}
We examine the degree to which required management courses in U.S.-based MBA programs make reference to the emerging evidence-based management (EBM) movement. More than 800 required management course syllabi from 333 programs were reviewed for either explicit reference to the concept of EBM, or verbiage within course descriptions that was consistent with teaching evidence-based management principles. In addition, instructor, course, and institution-level characteristics were examined as potential correlates of references to EBM. Using a liberal operationalization of EBM (i.e., keywords or phrases that are consistent with evidence-based management principles), results suggest that approximately $25 \%$ of core MBA management courses utilize EBM in some form. However, there are substantial differences across categories of course content and depending on whether the instructor has a $\mathrm{PhD}$. Evidence-based management-consistent syllabi are most prevalent at the MBA level in organizational behavior and least in international management and entrepreneurship. Suggestions for future research, as well as an exemplary course description from an EBM syllabus, are offered.
\end{abstract}

"The most obvious way that faculty research impacts practice is through education."

-AASCB International (Impact of Research Task Force, 2007: 37)

"Strengthening the teaching-research nexus holds vast potential to deliver not only the skills needed to understand research to generations of upcoming managers, but also to instill values that recognize the validity of research." -L. Burke and Rau (2010: 132)

It is hardly news that many managers and organizations do not implement practices that academic research has shown to be positively associated with employee productivity and firm financial performance (e.g., Hambrick, 1994; Johns, 1993; Pfeffer \& Sutton, 2000). Indeed, the failure to implement

This research was supported by a grant from the Management Education Research Institute (MERI). The authors would like to thank Rachel Edgington from MERI, Erin Donohue, Jean Bartunek, Ben Arbaugh, and the anonymous reviewers for their assistance and input. research-supported practices has been observed in nearly every field where there is a separation between those who conduct research and those who might implement research findings (Lewis, 2004; Rogers, 1995; Rynes, Bartunek, \& Daft, 2001; Straus, Richardson, Glasziou, \& Haynes, 2005). Over the past decade or so, attempts to deal with the research-practice gap have evolved in the form of movements toward "evidence-based" practice in such fields as medicine, education, marketing, rehabilitation, and psychology (APA Task Force, 2006; Ford, 2005; Law, 2002; Southworth \& Conner, 1999; Straus et al., 2005). Management is no exception to this trend (Pfeffer \& Sutton, 2007).

According to Rousseau (2006), "Evidence-based management means translating principles based on best evidence into organizational practices. Through evidence-based management (EBM), practicing managers develop into experts who make organizational decisions informed by social science and organizational research" (256). In other words, EBM attempts to move professional decisions away from reliance solely on personal preference, unsystematic experience, and idiosyn- 
cratic situational cues toward decisions based on the best available scientific evidence, which usually comes from large samples and large numbers of studies (as summarized by meta-analyses and other forms of systematic review; Tranfield, Denyer, \& Smart, 2003).

In order for EBM to take root, managers must be exposed to, understand, and embrace scientific evidence. Although this point may seem obvious, it is hardly trivial. For example, unlike medicine, education, or law, management is not truly a profession (Leicht \& Fennell, 2001; Trank \& Rynes, 2003). Specifically, there is no requirement that managers be exposed to scientific knowledge about management, that they pass examinations in order to become licensed to practice, or that they pursue continuing education in order to be allowed to maintain their practice. ${ }^{l}$ Furthermore, since the first choice of most managers seeking information is to consult with other managers (e.g., Brown \& Duguid, 2002; Wenger, McDermott, \& Snyder, 2002), and since extremely few managers read academic publications (Rynes, Colbert, \& Brown, 2002), the question of how to inform managers about scientific evidence remains open.

One means through which aspiring managers can learn about management-related evidence is by way of formal education in MBA programs (L. Burke \& Rau, 2010; Rousseau \& McCarthy, 2007). We chose to focus on MBA programs (vs. undergraduate business programs) in this study for several reasons. First, MBA programs have served as a major supplier of formal business education for many years, encompassing approximately $25 \%$ of the entire U.S. graduate school population since 1995 (U.S. Department of Education, 2009), and approximately $30 \%$ of the worldwide population of newly minted MBAs (Broughton, 2009). Total graduates from MBA programs in the U.S. topped 150,000 in the 2006-2007 academic year alone (U.S. Department of Education, 2009). Second, several scholars have recently urged business schoolsspecifically, MBA programs-to revise their current educational philosophy, pedagogy, and curriculum (e.g., Bennis \& O'Toole, 2005; Khurana, 2007; Mintzberg, 2005; Navarro, 2008; Rubin \& Dierdorff, 2009), including calls for greater emphasis on EBM (Rousseau \& McCarthy, 2007). Finally, several highly regarded business programs in the United

\footnotetext{
${ }^{1}$ Of course, there are subfields in management that do have certification and continuing education programs, including human resources (PHR/SPHR/GPHR) and project management (PMP). While these certifications are well respected and established in the field, there are no legal mandates that practitioners in either of these areas possess these certifications.
}

States (e.g., Harvard, Princeton, Columbia, Northwestern, Duke, and Stonford) do not offer undergraduate business programs. For these reasons, focusing on MBA programs seemed a prudent choice for this analysis. ${ }^{2}$

In addition, MBA programs seem an ideal venue for presenting the results of EBM research, as well as for helping students learn how to frame and solve problems using research-based evidence (L. Burke \& Rau, 2010; Rousseau \& McCarthy, 2007). John Reed, former chairman of Citigroup and president of the New York Stock Exchange, noted:

I believe it is very important for business practice to be shaped by basic research and basic knowledge. Research that draws from the academic disciplines (but in an interdisciplinary way) serves the important function of creating a framework that allows managers and management practitioners to understand the context and content of the specific problems they are dealing with (quoted in Augier, 2006: 88).

Yet, despite the promise of graduate management education as a venue for disseminating research-based knowledge, there is little broadbased evidence concerning what happens in management classrooms-particularly with respect to whether what is taught is consistent with the emerging EBM paradigm (L. Burke \& Rau, 2010). Our twofold purpose here is to examine (1) the extent to which U.S.-based MBA education appears to embrace on EBM perspective, and (2) the characteristics of courses, instructors, and institutions that are more likely to embrace the EBM paradigm.

\section{HYPOTHESES}

At the most general level, we are interested in determining the extent to which management course syllabi espouse the use and value of presenting research findings and evidence in management instruction. Emphasis on research findings and other evidence in course syllabi would be consistent with using the best available evidence to drive decisions and action, a practice at the heart of evidence-based movements in medicine,

\footnotetext{
${ }^{2}$ To further aid in an effort to narrow our focus, we chose to examine only full-time MBA programs based in the United States. While there are certainly full-time MBA programs throughout the world-and increasingly many part-time MBA programs-there is substantially more publicly available information via the media and the accrediting body (AACSB) on full-time, U.S.-based programs.
} 
education, and psychology. Because the syllabus is the first document provided to students and provides a comprehensive overview of most (if not all) aspects of a course, examining syllabi to see whether they mention the importance of judging the quality of evidence or using research and other evidence to make decisions provides useful insight into whether EBM is being incorporated into management instruction.

Assuming there is variance in the incorporation of EBM in teaching, it is also interesting to examine where EBM is most likely to be embraced. One likely source of variance involves characteristics of the instructor. Specifically, we would expect that individuals with research training (i.e., doctoral degrees) will be more likely than others to adopt EBM. Such individuals have the appropriate knowledge to understand research findings, and thus, should be readily able to present and discuss those findings in their classrooms. They are also more likely than non- $\mathrm{PhD}$ faculty to read research journals in the first place (Rynes et al., 2002). In a similar way, individuals who have $\mathrm{PhDs}$ are more likely to have published in scholarly journals and to be aware of and comfortable in teaching research evidence. Thus, we predict:

Hypothesis 1: Instructors with doctoral degrees will be more likely to incorporate evidence-based management in their instruction.

Hypothesis 2: Instructors with higher numbers of research publications will be more likely to incorporate evidence-based management in their instruction.

In addition to instructor differences, there may also be differences in the incorporation of EBM across different types of management subfields (e.g., organizational behavior $[\mathrm{OB}]$, human resource management [HRM], international management [IM]). For example, because the research base of an academic field increases with growth in its membership (e.g., Hambrick \& Chen, 2008), we might expect to find more mention of EBM in subfields of management that have larger numbers of researchers and, by extension, larger research bases.

Moreover, it has long been known that the adoption of innovations (such as EBM) is a social process, with innovation first spreading from a core of innovators to others who are similar and known to them, and only later to those who are less similar and less known (Rogers, 2003). Institutional theory (DiMaggio \& Powell, 1983) similarly suggests that in the face of uncertainty about the best course of action, mimetic forces may lead decision makers to copy the proctices of highly respected others.
In the case of EBM, the best-known, most widely read, and most prolific authors are arguably from OB (e.g., Latham, 2009; Locke, 2003, 2009; Pearce, 2009; Pfeffer \& Sutton, 2006; Rousseau, 2006). Thus, consistent with both institutional theory and prior research on the spread of innovations, we would expect EBM to be most prevalent in OB. More specifically, we propose:

Hypothesis 3: In terms of membership, larger subfields of management (e.g., OB, strategic management) are more likely to incorporate EBM than smaller subfields (e.g., IM, entrepreneurship).

Hypothesis 4: $O B$ courses will have the highest rate of EBM adoption among management subfields.

Continuing in management subfield delineations, Biglan (1973) demonstrated that subject matter areas in academia differ along three dimensions: paradigm existence (described as "hard" vs. "soft" science, where established paradigms may be lacking), concern with applications (i.e., pure vs. applied science), and concern with living or organic subjects. Previous research on differences among academic disciplines has also looked at specific facets of university-level teaching, including student assessment. For example, Warren Piper, Nulty, and O'Grady (1996) found that "hard" disciplines weighed examinations in student assessment more strongly than "soft" fields. For this study, we expect that where EBM principles are present in a syllabus, student performance is more likely to be assessed by way of examinations than in courses without an EBM focus. Our logic aligns with the Warren Piper et al. (1996) study in that instructors who place more emphasis on examinations probably do so because they believe there are research-based "facts" and "principles" (i.e., "hard" science) that are amenable to testing and objective grading. Thus, we predict:

Hypothesis 5: Examinations will comprise a higher proportion of student grades in EBMconsistent courses.

Institution-level characteristics may also influence the degree to which a particular course is evidence based. In particular, we expect three institutional characteristics to influence the incorporation of EBM into teaching, most likely through the attraction of highly productive researchers as instructors: institutional ranking based on research dollors, presence of a doctoral business program, and MBA program ranking. Faculty at institutions receiving more research dollars and hosting doctoral programs should be more likely to follow general institutional norms in espousing the value of research. Also, research in various 
fields of study, including medicine (Steiner, Lanpheor, Curtis, \& Vu, 2002); economics (Fox \& Milbourne, 1999); and accounting (Maranto \& Streuly, 1994) have found that research funding levels are positively related to research productivity. It is also logical to suggest that the presence of $\mathrm{PhD}$ programs will boost faculty research productivity. ${ }^{3}$ Finally, prior research has found a positive relationship between business school rankings and the research productivity of its faculty (Mitra \& Golder, 2009). Thus, institutions that can attract more productive researchers to serve as instructors-through higher levels of funding, in-house PhD programs, or a high-ranking MBA programshould also have a greater propensity toward teaching from an evidence-based perspective. Therefore, we propose:

Hypothesis 6: EBM-based instruction will be more prevalent at institutions with higher research funding.

Hypothesis 7: EBM-based instruction will be more prevalent at institutions with doctoral programs.

Hypothesis 8: EBM-based instruction will be more prevalent at institutions with more highly ranked $M B A$ programs.

\section{METHODS}

\section{Sample and Data Collection}

We began with the 2007-2008 database of AACSBaccredited schools and selected only those that were U.S. based and had full-time MBA programs $(N=378)$. We began collecting programmatic information by way of university-hosted websites for prospective MBA students. We identified the number of overall required courses and the number of required courses in management, the latter of which (for purposes of this study) included $O B$, HRM, IM, strategy, communications, business law, ethics, entrepreneurship, negotiations, and general management. Courses with a predominantly

\footnotetext{
${ }^{3}$ Our search for evidence to support this assertion proved more difficult than we anticipated. Many of the studies on institutionallevel research productivity use a National Research Council dataset, which only has data on departments with doctoral programs (see http://sites.nationalacademies.org/PGA/Resdoc). However, it is certainly conceivable that the addition of $\mathrm{PhD}$ students to a department would increase the resources available for conducting research, and thus increase research productivity. Likewise, faculty in business schools with doctoral programs must teach doctoral seminars and serve on doctoral committees as part of their regular job duties. For that reason, they should be more familiar with the management literature and thus better prepared to incorporate that literature into their MBA courses.
}

technical focus (e.g., finance, operations, accounting, statistics, or economics) and marketing courses were not included.

Once the required management courses had been identified, we then attempted to download syllabi from the website. If a particular syllabus was not publicly available, we sought contact information for the instructor(s) who most recently taught the course and sent requests for syllabi directly to them. If we did not receive a reply after two e-mail attempts, we followed up with at least one phone call. Approximately half the syllabi collected came by way of the Internet, while the remaining syllabi were retrieved by way of personal contact (e-mail or phone) with the course instructor.

From the total number of required management courses ( $n=1431)$ across all accredited programs, we succeeded in collecting 834 unique syllabi (58\%). Eight syllabi were eliminated from our analysis due to a substantial lack of study-relevant data (e.g., syllabus contained only a schedule of topics to be covered), bringing the final total of analyzed syllabi to 826. At the institutional level of analysis, we collected at least one viable syllabus from 333 of the 378 potential schools (88\%).

\section{Measures}

\section{Evidence-Based Management}

We used two approaches to assess whether a course was evidence based, as demonstrated by the information contained in the syllabus. Syllabi data were first coded into a Microsoft Access database, including all narrative passages about the course (e.g., introduction, course description, course objectives). We then conducted an electronic search in Microsoft Access using the "Find" function for the entire database of syllabi for the specific phrase, "evidence-based management." This search produced only 2 results, in course overviews from two $O B$ courses taught at different institutions. These two references were as follows:

- We also will focus on learning about "evidencebased management" which is an approach that encourages us to use data-driven ideas and clear and critical thinking regarding management practice.

- This course is an introduction to Organizational Behavior. An important component of this class is a focus on critical thinking and evidence-based management.

Because of the very few instances of direct mention of EBM, we developed a more liberal operationalization of the presence of EBM-consistent in- 
struction. Specifically, we searched the database (e.g., learning objectives, norrative course description) for key terms (such as "research" or "evidence") or phrases that were reflective of EBM. This search resulted in 216 cases where EBM terms were found in the appropriate context. Three examples of these indirect references to EBM in syllabi include:

- The views provided will be not those of the individual professor ... but rather the consensus opinions of experts across a number of fields regarding the most up-to-date research and theoretical findings.

- Strategic management deals with the firm and its environment, including the global environment, and the focus is on competitive advantage and core competencies. The typical processes include formulation, implementation, control, and evaluation of strategies. Our focus will be to understand current theories, examine existing research, and to critically examine this complex field.

- Students should be able to evaluate management advice and separate advice that will truly nourish and grow your organization from advice that sounds good but is not evidence based.

Each syllabus containing a statement similar to the ones above was coded as a "l" for EBM and "0" otherwise.

In contrast, some syllabi used the terms "research" or "evidence," but the usage was not within the context of EBM. Examples include:

- Differences in the nature of the research and development functions and in the skills required of engineers and scientists create special problems for the manager ...

- In addition to the course content, the class will help you further develop important skills: research skills, analysis, creative thinking, critical thinking, and problem solving.

- Granted, learning rocket science is a major challenge, but when you're done at least you have a very good chance of predicting where a rocket will land (if all systems are "go"). This, however, is a course in human behavior. The subject matter of the course comes from the same investigatory principles that govern rocket science, but predicting where human behavior will "land" is much more difficult. Just when you think you understand people you're likely to encounter evidence that disconfirms your hypotheses.

Despite the use of the terms "research" or "evidence," these particular quotes do not suggest that prior evidence from research studies will be reviewed in the course. Hence, syllabi with statements such as these were coded as " 0 " for EBM if no further evidence of EBM focus was found within the document. Additional information on the coding process for independent variables, raters, and interrater agreement is provided in the following sections.

\section{School Variables}

Our measure of research ranking was based on the 2005 National Science Foundation ranking of institutions based on the level of grant funding received by the entire institution. This was the most recent publication of the NSF rankings at the onset of the data coding process. If the program was not listed in the rankings, a zero was entered (range = 0 to 630). Existence of a business-related $P h D$ program was coded dichotomously (" 1 " for yes, " 0 " for no). Ranking of $M B A$ program was measured by examining 2008 rankings of four publications: BusinessWeek, Forbes, US News and World Report, and Financial Times. The number of publications in which a program was ranked (range $=0$ to 4 ) was entered for each institution. In addition, we also collected two other institution-level variables to assess the representativeness of our sample. These were funding source (" 1 " for private, "0" for public) and religious affiliation (" 1 " for yes, "0" for no).

\section{Instructor Variables}

To assess Hypothesis 1, a dichotomous variable was created to capture whether the instructor held a $P h D$. Originally, we sought this information on the syllabus itself. However, because many syllabi did not indicate whether the instructor had a PhD, in these cases we went to the school's website to find the faculty member's curriculum vitae, biography, or web page. Failing that, we did a more general web search using Google and Google Scholar. For analysis purposes, we recorded both whether the instructor had a $\mathrm{PhD}(1=$ "yes" and $0=$ "no") and whether it was annotated on the syllabus. For courses that were team taught $(n=55)$, the variable was coded as a "l" (yes) if any of the listed instructors had a $\mathrm{PhD}$.

To assess Hypothesis 2, a web search using the ProQuest database was performed to capture the number of scholarly publications for each instructor (instructor publications; range 0-81). For courses that were team taught, the individual with the highest number of publications among the listed instructors was selected. In addition, we coded two other variables related to instructors. Specifically, we created dichotomous variables to differentiate courses that were team led, or that utilized an adjunct instructor ("0" for no, "l" for yes). 


\section{Course-Specific Variables}

To examine whether EBM-consistent courses differed in reliable ways, three broad course-related features were coded. First, the course was categorized according to its primary content-OB, HRM, IM, law/ethics, strategy, entrepreneurship, general management, communication, and (for courses with emphasis in more than one area), multiple. Second, with respect to Hypothesis 3, which predicted that the adoption of EBM would be associated with subfield size, membership statistics for each Academy of Management (AOM) division associated with the types of courses included in this study (e.g., organizational behavior, strategy, entrepreneurship) were obtained from the AOM website. A third area which was captured for each course syllabus was the grading scheme. Grades for each course were broken down into seven categories: participation, individual written assignments, individual presentations, group writing assignments, group presentations, tests, and other assessments (i.e., simulations and peer evaluations). For each, the percentage weighting of each category in the total grade was captured.

\section{Interrater Reliability}

Two initial subsets of syllabi were coded by the first author and a trained undergraduate student to test interrater reliability and ensure standardization in the coding process. The first set of 15 course syllabi yielded an $80 \%$ rate of identical coding of study independent variables. Cases where the coders disagreed were discussed, and subsequent coding instructions were modified to reduce the sources of initial discrepancies. The second subset of 15 syllabi yielded 95\% rater agreement across all independent variables. In total, roughly $50 \%$ of the syllabi were coded by the first author, $45 \%$ by the undergraduate student assistant, and $5 \%$ by both individuals.

For the dependent variable (evidence of EBM), the first author performed the keyword searches as described previously. Subsequently, the first and second authors collectively reviewed the use and context of EBM keywords for all instances and determined the final coding of EBM for each syllabus by way of consensus.

\section{Sample Representativeness}

A multivariate analysis of variance (MANOVA) was completed at the institutional level to compare schools where we obtained at least one syllabus against schools where we obtained none. A significant difference between groups was indicated from the analysis (Wilks' lambda $=.96, F(7$, $370)=2.26, p<.05$ ). Follow-up univariate analyses revealed significant differences along two variables: ranking of $M B A$ program, as assessed by the number of publications in which a program was ranked [represented group $M=.50$, missing group $\left.\left.M=.13 ; F(1,376)=3.95, p<.05, \eta^{2}=.01\right)\right]$, and the number of required management courses [represented group $M=3.88$, missing group $M=3.16 ; F(1$, $\left.376)=7.36, p<.01, \eta^{2}=.02\right]$. The pattern here suggests that represented schools have higher national rankings (on average) and require more management courses than nonrepresented ones.

As can be seen, however, both observed effect sizes are small. They also are not surprising. First, we made a concerted effort (i.e., more than two phone call follow-ups) to acquire syllabi from programs that were ranked in at least two of the four publications ${ }^{4}$ such that in the end, only 2 of these 51 programs did not contribute at least one syllabus ( $4 \%$ missing data). In contrast, the missing data rate across the full sample of programs was $12 \%$ (45 programs out of 378 ). It is also not surprising that the groups differed in terms of number of required management courses, as a higher base rate of qualifying syllabi at a given program should naturally translate into a greater likelihood of having one or more syllabi included in this study. Thus, given these small differences between included and nonincluded programs, we feel confident that our institution-level data are reflective of the full complement of AACSB-accredited fulltime programs in the United States.

\section{RESULTS}

Descriptive statistics and correlations are presented in Table 1 . In the sample of syllabi obtained, $87 \%$ of courses were taught by instructors with a $\mathrm{PhD}$, while only small percentages of courses were taught by adjunct instructors $(6 \%)$ or instructional teams (6\%). Consistent with the population of AACSB-accredited full-time MBA programs in the United States in 2008, our sample of institutions for which at least one syllabus was collected consisted largely of public (68\% sample, $70 \%$ AACSB), nonreligious affiliated (86\% sample, $85 \%$ AACSB) institutions without doctoral programs (59\% sample, $67 \%$ AACSB). In terms of direct representation of EBM in course syllabi, as noted

\footnotetext{
${ }^{4}$ We felt that having good representation from the relatively small number of nationally ranked programs was essential to ensure adequate variance within the sample.
} 
TABLE 1

Descriptive Statistics and Correlations

\begin{tabular}{|c|c|c|c|c|c|c|c|c|c|c|c|c|c|c|c|c|}
\hline Variable & $M$ & $S D$ & $N$ & 1 & 2 & 3 & 4 & 5 & 6 & 7 & 8 & 9 & 10 & 11 & 12 & 13 \\
\hline 1. Instr PhD & .87 & .34 & 815 & & & & & & & & & & & & & \\
\hline 2. Instr PhD Listed & .49 & .50 & 815 & $.38^{*}$ & & & & & & & & & & & & \\
\hline 4. Instr Team & .06 & .25 & 819 & .03 & $-.08^{*}$ & -.03 & & & & & & & & & & \\
\hline 5. Instr Publications & 8.87 & 10.62 & 815 & $.26^{*}$ & -.03 & $-.20^{\star}$ & $.23^{*}$ & & & & & & & & & \\
\hline 6. Test as $\%$ of Grade & 31.46 & 25.92 & 810 & -.05 & .00 & $-.08^{*}$ & $-.09^{*}$ & $.09^{*}$ & & & & & & & & \\
\hline 9. Sch NSF Rank & 177.63 & 171.94 & 826 & -.04 & $.11^{*}$ & .00 & $-.10^{*}$ & $-.12^{*}$ & .04 & -.03 & $.12^{*}$ & & & & & \\
\hline 10. Sch PhD Prog & .41 & .49 & 826 & -.03 & $-.19^{*}$ & .03 & $.07^{*}$ & $.13^{*}$ & .01 & .00 & $-.28^{*}$ & $-.39^{*}$ & & & & \\
\hline 11. Sch MBA Rank & .76 & 1.42 & 826 & .01 & $-.31^{*}$ & .01 & $.16^{*}$ & $.21^{*}$ & -.03 & $.30^{*}$ & -.04 & $-.39^{*}$ & $.52^{*}$ & & & \\
\hline 12. Sch Reqd Mgmt & 4.51 & 2.06 & 826 & -.03 & $-.14^{*}$ & -.03 & $.17^{*}$ & $.09^{*}$ & $-.16^{*}$ & $.19^{*}$ & .04 & $-.12^{*}$ & $.24^{*}$ & $.26^{*}$ & & \\
\hline 13. AOM Div Total & 4312.12 & 1728.47 & 702 & $.44^{*}$ & $.18^{*}$ & $-.11^{\star}$ & -.02 & $.08^{*}$ & .01 & $-.08^{*}$ & $-.08^{*}$ & -.02 & .00 & .00 & $-.16^{*}$ & \\
\hline 14. EBM & .26 & .44 & & $.18^{*}$ & $.11^{*}$ & -.04 & -.01 & $.11^{*}$ & $.10^{*}$ & -.02 & -.05 & -.06 & .07 & $.09^{*}$ & $-.08^{*}$ & $.28^{*}$ \\
\hline
\end{tabular}

Note: the maximum sample size for all bivariate correlations with this variable was 702, as all syllabi under the General Management and Multiple categories did not align with an AOM division, and were thus excluded from this portion of the analysis.

Instr = Instructor; Sch = School/Institution; Sch PhD Prog = School/Institution that support a PhD program in business; Sch Reqd Mgmt $=$ Number of required management courses in the school/institution MBA program; AOM Div Total = Total membership in related Academy of Management division as of February 2010.

${ }^{*} p<.05$.

earlier, only 2 syllabi actually used the term "evidence-based management." However, using the more liberal operationalization, $26 \%$ of syllabi included EBM-related statements.

At the bivariate level, Table 1 and Figure 1 suggest that instructors with $\mathrm{PhDs}(r=.18, p<.01)$ are more likely to produce EBM-consistent syllabi than those without doctorate degrees (supporting Hypothesis 1). Instructors with more publications are also more likely $(r=.11, p<.01)$ to adopt EBM principles in their syllabi (supporting Hypothesis 2). There also was a positive relationship between adoption of EBM principles in course syllabi and proportion of student grades based on exams (Hypothesis $5, r=.10, p<.01)$. It is notable that for Hypotheses 6 and 7, there were no reliable differences in terms of institutional research funding rank $(r=-.06, p>.05)$ or presence of $a$ business doctoral program $(r=.07, p>.05)$. Finally, more syllabi were EBM consistent in higher ranked MBA programs (Hypothesis 8, $r=.09, p<.05$ ).

Hypotheses 3 and 4 suggest that there will also be differences across course content (i.e., management subfield). Table 2 reveals that this is indeed the case $\left(\chi^{2}(9)=22.32\right.$, Cramer's $\left.V=.16, p<.01\right)$. Consistent with Hypothesis 3, there was a strong

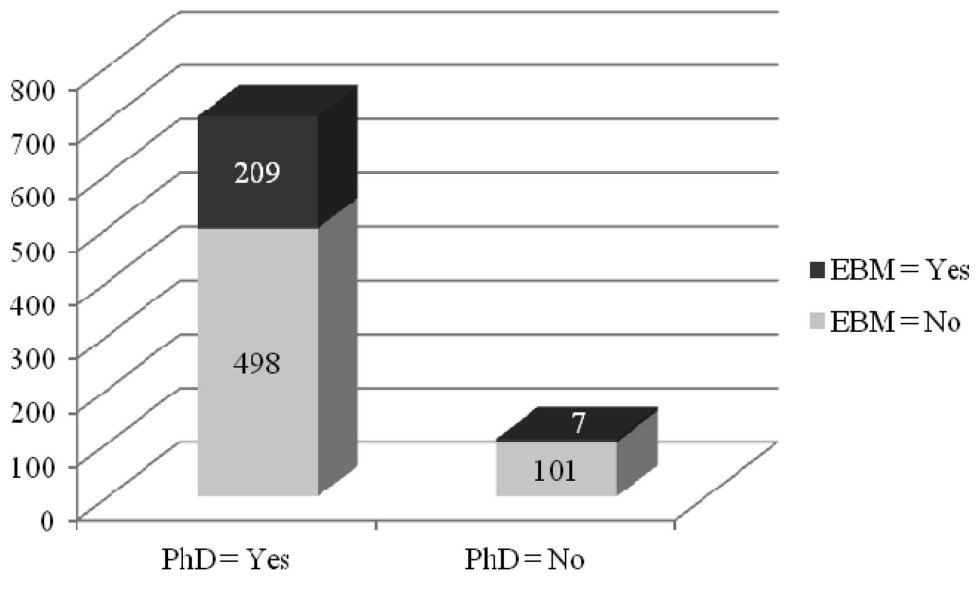

FIGURE 1

Number of Management Instructors With PhDs Versus Non-PhDs Who Use EBM-Consistent Syllabi in Required MBA Courses 
TABLE 2

EBM by Course Content

\begin{tabular}{lrrr}
\hline & \multicolumn{3}{c}{ EBM Overall } \\
\cline { 2 - 4 } \multicolumn{1}{c}{ Course Category } & \# EBM & Total & $\%$ \\
\hline Communications & 4 & 25 & 16.0 \\
Entrepreneurship & 1 & 9 & 11.1 \\
General Management & 17 & 73 & 23.3 \\
HRM & 7 & 24 & 29.2 \\
International & 9 & 70 & 12.9 \\
Law \& Ethics & 8 & 104 & 7.7 \\
Multiple & 11 & 53 & 20.8 \\
Negotiations & 1 & 8 & 12.5 \\
OB & 119 & 249 & 47.8 \\
Strategy & 39 & 211 & 18.5 \\
Total & 216 & 826 & 26.2 \\
\hline
\end{tabular}

correlation $(r=.75, p<.01)$ between number of AOM members per subfield and percent of EBMconsistent courses. This should be interpreted cautiously, as the number of discrete data points (i.e., AOM membership per course category/management subfield) was quite small $(n=8)$. And consistent with Hypothesis 4, OB courses had by far the highest proportion of syllabi referencing EBM $\left(\chi^{2}(1)=83.66\right.$, Cramer's $\left.V=.32, p<.01\right)$. Figure 2 graphically shows the relationship between subfield size and proportion of EBM-consistent courses.

To examine multivariate effects, we also conducted a logistic regression to see which instructor, subfield, and institutional characteristics were related to EBM-consistent syllabi. ${ }^{5}$ Results are presented in Table 3. Consistent with Hypothesis 1, a large effect was obtained for instructor $\mathrm{PhD}$ (oddsratio of $3.62, p<.05$ ). Contrary to the significant bivariate relationship reported previously for $\mathrm{Hy}^{-}$ pothesis 2, number of instructor peer-reviewed publications was not a significant predictor of EBM in the logistic regression (odds-ratio of 1.01, $p>$ .10). With respect to Hypothesis 4, OB courses were more likely to have EBM-consistent syllabi (oddsratio of 2.97, $p<.01$ ) than courses from other subfields. Support was also found for Hypothesis 5, that $a$ higher proportion of course grades would be based on examinations in EBM-consistent classes, although the effect size was quite small (oddsratio $=1.01, p<.05)$. The mean percentage of

\footnotetext{
${ }^{5}$ Because there were numerous cases of multiple syllabi from a single institution, error terms are not entirely independent in this analysis. Although this non-independence biases standard errors (and thus estimates of statistical significance), estimates of effect sizes remain unbiased (Pindyck \& Rubinfeld, 1981).
}

TABLE 3

Regression Model on EBM

\begin{tabular}{lccr}
\hline \multicolumn{1}{c}{ Variable } & $\boldsymbol{\beta}$ & SE & Exp $(\boldsymbol{\beta})$ \\
\hline Instr PhD & $1.287^{*}$ & .504 & 3.622 \\
Instr PhD Listed on Syll & .334 & .199 & 1.397 \\
Instr Adjunct & .652 & .474 & 1.919 \\
Instr Team & -.078 & .381 & .925 \\
Instr Publications & .012 & .009 & 1.013 \\
Test as \% of Grade & $.007^{*}$ & .004 & 1.007 \\
Sch Private & .113 & .250 & 1.120 \\
Sch Religious & -.253 & .342 & .776 \\
Sch NSF Rank & .000 & .001 & 1.000 \\
Sch PhD Program & .075 & .224 & 1.078 \\
Sch MBA Rank & $.170^{*}$ & .080 & 1.185 \\
Sch Reqd Mgmt & $-.095^{*}$ & .047 & .909 \\
Course Category & & & \\
Communications & .204 & .688 & 1.226 \\
Entrepreneurship & -.564 & 1.136 & .569 \\
General Mgmt & .230 & .458 & 1.259 \\
HRM & .443 & .583 & 1.558 \\
International & -.703 & .520 & .495 \\
Law/Ethics & -.777 & .522 & .460 \\
Negotiations & -.722 & 1.177 & .486 \\
OB & $1.088^{*}$ & .375 & 2.967 \\
Strategy & -.241 & .394 & .786 \\
Constant & $-2.716^{*}$ & .654 & .066 \\
\hline
\end{tabular}

Instr = instructor; Syll = syllabus; $\mathbf{s c h}=$ school; Reqd $=$ Required.

$N=802$, due to missing data in some of the independent variables.

Nagelkerke $R^{2}=.22$.

${ }^{*} p<.05$.

course grade tied to examinations in EBMconsistent courses was $35.58 \%$, versus a mean of $29.95 \%$ in non-EBM courses. No significant differences were found for ranking of research funding (Hypothesis 6) or presence of a business PhD program (Hypothesis 7). Finally, EBM-consistent programs were also more likely to be found in higher ranked MBA programs (Hypothesis 8, odds-ratio = 1.18, $p<.05$ ). The mean number of publications ranking the overall MBA program for a given course was 0.97 for EBM-consistent syllabi, versus 0.68 for non-EBM courses.

Finally, in the interest of providing a model that instructors who wish to teach in an evidencebased manner might emulate, we include the "Course Description" section of an organizational behavior syllabus developed by Amir Erez, which was itself based on an earlier syllabus of Tim Judge's (see Exhibit). This syllabus stood out as one of the best exemplars of EBM-based teaching in our sample. In response to our request for permission to include part of his syllabus in this article, Professor Erez wrote (e-mail communication, January 19, 2011): 


\begin{tabular}{|c|}
\hline EXHIBIT \\
Course Description of OB Syllabus \\
\hline$\frac{\text { Organizational Behavior }}{\text { Professor Amir Erez }}$ \\
University of Florida
\end{tabular}

Course Description

"People are our most important asset."

This stock phrase can be found, in one form or another, in most annual reports and CEO speeches. Is it true? Certainly, nearly all managers would agree that managing people effectively is an important ingredient of organizational effectiveness. In fact, a recent analysis of the world's most admired companies concluded that the most important success factor was the effective acquisition and management of people. Most managers would further argue, however, that managing people effectively, and developing competent "soft" (interpersonal) skills, is not something you can learn in a class. Rather, good people skills are a matter of experience and "street smarts." Ergo,

"Managing people effectively and good soft skills are important, but they are simply matters of keen intuition, experience, and common sense."

The first part of the above statement is right but the latter part is wrong. I am not denying that experience and good intuition are helpful in managing people and interpersonal relations. Unfortunately, common sense, experience, and intuition often fail to provide accurate knowledge of behavior. And when our convictions about behavior are inaccurate, it is often difficult to know how badly they've served us. Even if we discover our errors, we often become uncritical consumers of faddish remedies. They mostly comfort our intuitions and increase organizational costs, but rarely have positive effects on individual or organizational performance.

It needn't be this way.

How would your chosen organization react if you justified a capital expenditure with only intuition and common sense? Finance is important to business enterprises because it works-it allows us to accurately justify our investment decisions and to analyze their effectiveness. Why should we manage people any differently?

There has amassed a literature on behavioral science methods and findings that can be used to enhance the effective management of people and development of useful soft skills that can be used on a daily basis to improve personal and organizational performance. This literature is not easily learned and thus the problem: $\mathrm{A}$ manager or an organization can get by with "seat of the pants" management in the short run, but this will not provide them with one of their principal sources of sustained and sustainable competitive advantage. But within the problem lies the opportunity: Because so few organizations have the knowledge and/or discipline to apply behavioral science methods and findings to their organizations, those who do can achieve a competitive advantage. It's not easy. It takes time. It takes discipline and commitment in the absence of immediate reinforcement. But it works.

My goal is to show you and convince you that understanding how to manage people (AKA Organizational Behavior), is (a) important and (b) more a matter of learning and knowledge than common sense and intuition. I seek to teach you both content and process skills. With respect to content, we will

\section{EXHIBIT
(Continued)}

learn what the research literature has to teach us about effectively managing people. In terms of process skills, we will learn how to analyze people problems you will encounter in the future without sole reliance on intuition and business fads. Should you learn, accept, and commit to using these tools, they can be very helpful to you.

You will not see as many company examples in class as you might expect. There are several reasons for this. First, many companies are not using scientifically sound processes in managing their people. So, examples of organizational practice, such as those that appear in the business weeklies, are often flawed examples. More importantly, we have a limited amount of time together. Time we spend discussing the latest management fad is time taken away from learning how theories and research findings can be applied practically in organizations. To be sure, we will spend a great deal of time discussing applications. But it will be easier for you to read Fortune once this class is finished than to learn about research findings from the Journal of Applied Psychology.

Now you know my strategy. Below I provide details and tactics that put the strategy in motion.

By the way, this is exactly how I teach the class. The entire theme of the class is to show students how our intuitions and common sense fail us and how a research approach can help us in overcoming some of these problems. In some of my classes (decision making, negotiation), students experience firsthand how their intuitions fail them (which really ticks them off) and in others I explain why these problems happen, using research mainly from cognitive psychology and neuroscience. Students also learn how to conduct research on their own (I have two methods classes and in the class project which is $45 \%$ of their grade they have to analyze data and reach managerial conclusions based on these data). Students react very well to this approach, especially at the executive/professional level.

\section{DISCUSSION}

Our study represents a first attempt to examine the question of whether EBM has made its way into MBA classrooms in the United States. When viewed very conservatively as to whether course syllabi use the specific term "EBM," the answer is "no." However, when viewed more broadly, we find a sizable minority of courses (26\%) that address issues of research evidence in their syllabi.

Our formal hypotheses dealt with questions 
about which instructor, institutional, and course characteristics are more likely to be associated with EBM. With respect to instructors, we found that EBM was much more likely if the instructor had a PhD than if he or she did not. This suggests that the trend toward hiring more adjunct instructors (American Association of University Professors, 2007; Bureau of Labor Statistics, 2010) may work against EBM-consistent instruction, because adjunct instructors are less likely to have doctorate degrees $(r=-.42$, for the relationship between instructor $\mathrm{PhD}$ and adjunct instructor in our sample).

In addition, we found that EBM-consistent instruction was more likely in higher ranked MBA programs than in lower ranked ones. However, it was surprising that neither ranking of research funding nor the existence of a PhD-level business program had a significant effect on the use of EBM. It is possible that there is a level consistency issue with the NSF research-funding rank variable, as the funding level data we collected were for each university as a whole, and not specific to the funding procured by the business school or manage- ment department. As for the nonsignificance of the $\mathrm{PhD}$-program variable, it is worth noting that the regression coefficient was positive and that the bivariate correlation with EBM instruction $(r=.07)$ had a $p$ value only slightly above $.05(p=.053)$. Still, it is perplexing that a program characteristic that we believed a priori would have a significant positive impact on the use of EBM in MBA management courses did not. Further research as to why this is so is needed.

With respect to course content, consistent with our predictions, we found that instructors from larger subfields were considerably more likely to mention EBM-consistent principles in their syllabi than were instructors from smaller ones. In addition, we found a much higher proportion of EBM in $O B$ than in other subfields, a difference that we predicted based on social influence and diffusion of innovation literatures. However, as Figure 2 indicates, there is somewhat less evidence of EBMrelated teaching in strategy than would be expected on the basis of field size, and somewhat more in HRM.

One possible explanation for the higher preva-

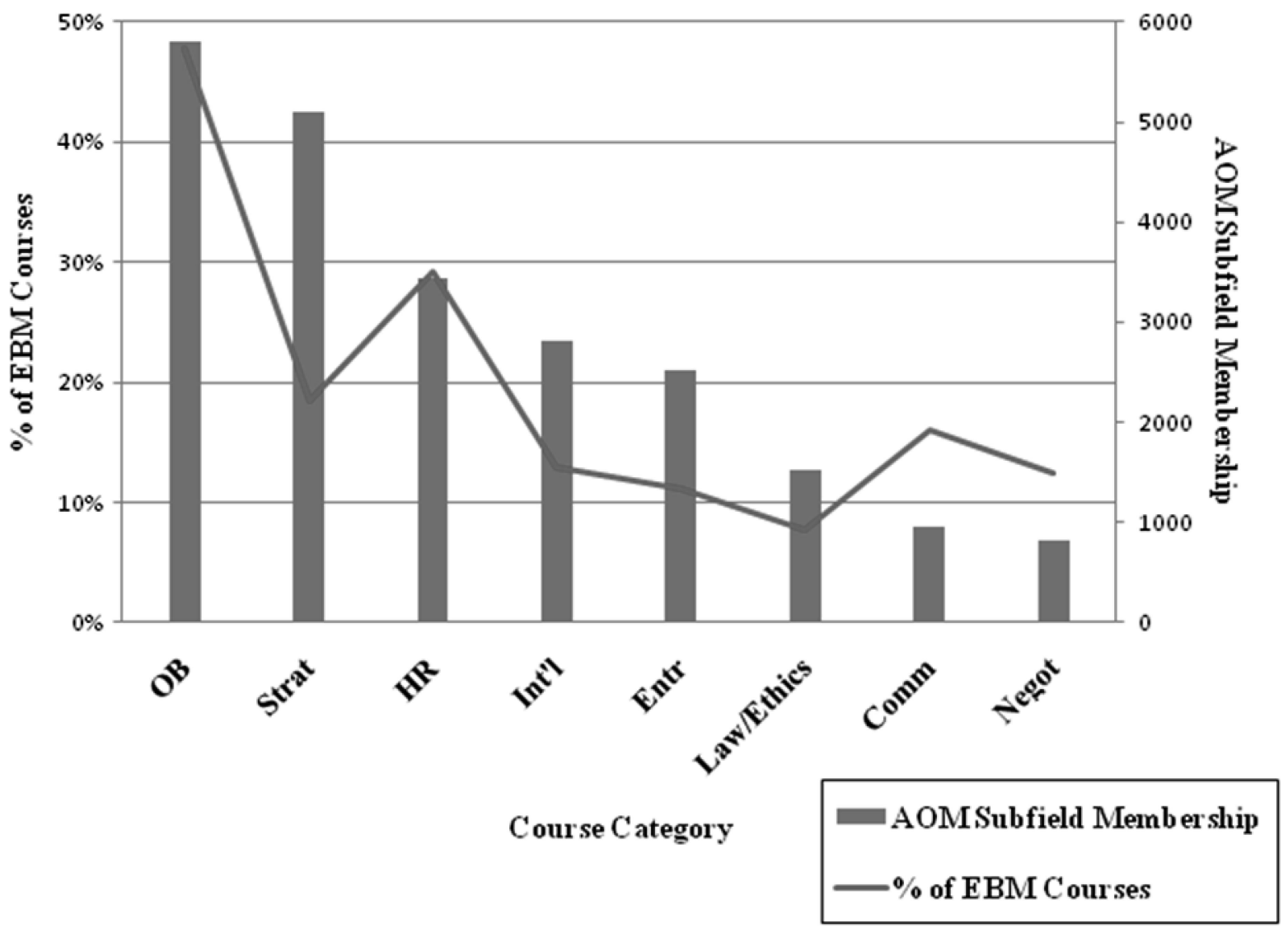

FIGURE 2

Relationship Between Size of Academy of Management Subfield Membership and Percentage of EBM-Related Management Courses 
lence of EBM in OB than other fields might be that the other management subfields are less likely to have a well-defined core body of knowledge (e.g., Cole, 1983; Hambrick, 2004), although this possibility has been disputed by others (e.g., Glick, Miller, \& Cardinal, 2007). A similar argument might be made that OB is a "harder" (as opposed to "softer") discipline than the others, in the sense of having specific, well-agreed-upon problems and consistent methods to solve them (see Biglan, 1973). Again, some have argued that precisely the opposite is true for OB (e.g., Blood, 1994; Glick et al., 2007; Pfeffer, 1993). Nevertheless, it is possible that we are witnessing the movement of $\mathrm{OB}$ as a field of study from "moderately soft" (L. Burke \& Moore, 2003) toward the "harder" end of the continuum. Although any of these explanations is certainly possible (e.g., see Hambrick, 2004, with respect to strategy), we are unable to assess this issue with the present dataset and propose this as an area for future research as well.

Our data do suggest a considerable role for social influence in adoption of an EBM perspective in teaching. Specifically, Figure 2 suggests a disproportionately low adoption of EBM in strategy (relative to its size) and disproportionately high adoption in OB and HRM. While high adoption of EBM in $\mathrm{OB}$ was predicted a priori, the relatively high adoption in HRM (which was not predicted) makes considerable sense after the fact. Several of the proponents of EBM in OB (e.g., Latham, Locke, \& Pfeffer) have written about EBM in the context of HRM as well (Latham \& Stuart, 2007; Latham \& Latham, 2003; Pfeffer \& Sutton, 2006). In addition, there is a considerable body of literature about the research-practice gop in HRM (M. Burke, Drasgow, \& Edwards, 2004; Cohen, 2007; Hutchins \& L. Burke, 2007; Latham, 2007; Rynes et al., 2002; Rynes, Giluk, \& Brown, 2007), a research area that is closely related to EBM in its concern for moving research findings into proctice.

As such, our results suggest a strong social aspect to the adoption and diffusion of EBM-related instruction in management, consistent with findings from institutional theory (DiMaggio \& Powell, 1983) as well as empirical research on social networks (e.g., Granovetter, 1973) and the diffusion of innovations (Rogers, 2003). In turn, our findings suggest that further diffusion of EBM to strategy and to smaller subfields of management may require an increase in strong ties between major content areas (especially $\mathrm{OB}$ and strategy; see Pearce, 2003), or a shift in diffusion from strong ties to weak ones. An increase in weak tie diffusion might also help foster the movement of EBM to non-nationally ranked MBA programs.

\section{LIMITATIONS AND FUTURE RESEARCH}

Our study represents a first step toward examining the adoption of EBM-consistent practices in management instruction in U.S. MBA programs. However, merely examining whether course syllabi contain language consistent with EBM cannot fully address what is actually taught in the classroom, and how. For example, there may be some teachers who routinely present research findings without mentioning this in the syllabus, and others who indicate that they will present research findings, but in reality, do not.

While our overall sample of required managementrelated MBA syllabi was quite large, some categories of course content were not well represented (e.g., entrepreneurship, negotiations). This may raise concerns over statistical power and the ability to generalize results from the study across the entire management education domain. While it is true that the sample size for some course categories is small, this is also reflective of the "state of the curriculum" in MBA programs in general; that is, these courses are generally not required in most U.S. MBA programs (see also Navarro, 2008).

One possibility is that both the low representation of these subfields in the MBA core as well as their limited use of EBM can be attributed to the fact that these subjects are relatively new, but are rapidly growing in terms of their research base. For example, Kirkman and Law (2005) demonstrated a significant increase in international management research in the Academy of Management Journal (AMJ) from 1970 to 2005, with much of that growth taking place in the period after 2000 . Also, a recent search on the term "entrepreneur" in AMJ article abstracts found 16 articles from 1985 to 1999, compared with 31 articles from the year 2000 through 2010 . These findings suggest that we may begin to see an uptick not only in representation of these courses in the MBA core, but also in the number of instructors who practice EBMconsistent teaching.

Although analyzing course syllabi had the advantage of providing a relatively large sample size, future researchers might examine consistency between EBM principles and actual teaching practices using other methodologies such as classroom observation, instructor surveys, or analysis of lecture notes and course readings. Such methods would allow for a more detailed analysis of what is currently being taught and how. For example, a full implementation of evidence-based principles in teaching would include not only presentation of research findings, but also instruction on how to evaluate the quality of research and how to think, 
design, and analyze problems the way a researcher does (Rousseau \& McCarthy, 2007). Thus, one avenue for future research is to expand the types of data collected and analyzed to determine how EBM is implemented across different MBA classes.

Another useful area for further investigation would be to determine whether the incorporation of EBM into management teaching is indeed associated with a stronger "body of knowledge" in some subfields than others (Biglan, 1973). For example, with respect to the relative underrepresentation of EBM-related strategy instruction found in our study, Hambrick (2004) suggested that strategy had not yet articulated a clear, agreed-upon body of findings despite the rapid growth in its membership and research base. In contrast, both OB (e.g., Locke, 2003, 2009; Pfeffer \& Sutton, 2000) and HRM (Deadrick \& Gibson, 2009; Fernandes-Alles \& Ramos-Rodriguez, 2009; Rynes et al., 2002, 2007) have been consolidating their knowledge bases for nearly a decade.

Yet another useful area for future research would be to examine student responses to EBMbased instruction, since there is the potential for negative reactions (Goodman \& O'Brien, 2010). First, business students tend to prefer practicefocused sources of material over academic ones (Rousseau \& McCarthy, 2007; Trank \& Rynes, 2003), a fact that may discourage teachers from using research-based textbooks and articles. Second, students (like all people) tend not to believe research findings that are inconsistent with their existing "frames" about how the world works (Rogers, 2003). Negative reactions to research findings that are inconsistent with one's prior beliefs occur in management (e.g., Rynes et al., 2002), as well as in scientific fields, such as physics (Halloun \& Hestenes, 1985), and climatology (Kahan \& Braman, 2006; Kahan, Jenkins-Smith, \& Braman, 2010). Third, the management arena has several important issues that have long provoked conflict among management scholars over mixed empirical findings, such as whether financial incentives are effective or dysfunctional motivators (see, e.g., Locke, Feren, McCaleb, Shaw, \& Denny, 1980, vs. Pfeffer, 1998, or Eisenberger \& Cameron, 1996, vs. Deci, Koestner, \& Ryan, 1999). Similarly, journalists frequently push "popular" themes that contradict research findings, such as the alleged superiority of "emotional" over "standard" intelligence (i.e., general mental ability; see Goleman, 1995, vs. Schmidt \& Hunter, 1998), the sole use of "intuition" over research-based actuarial models (e.g., Gladwell, 2005, vs. Highhouse, 2008), or the superiority of empowerment over financial rewards for motivating employees (e.g., Pink, 2009, vs. Gerhart \& Rynes, 2003). Given such controversies, it makes it easy for students to dismiss "stronger" research findings that conflict with their prior preconceptions (Specter, 2009), particularly when many management students are research- and math-phobic (Ayres, 2008; Paulos, 2001) and do not understand what makes one study stronger than another (L. Burke \& Rau, 2010; Rousseau \& McCarthy, 2007). In such an environment, future research related to whether, and why, students accept or reject EBM-based teaching would be highly desirable (see also Rousseau \& McCarthy, 2007).

Because teaching from an evidence-based perspective involves teaching not only "what" (i.e., research findings) but "how" (e.g., how to critically evaluate research claims and how to use general scientific findings in proctice), research is needed on what teaching practices could most readily produce such accomplishments (L. Burke \& Rau, 2010; Rousseau \& McCarthy, 2007). One very real issue for instructors is how to add this more technically difficult course material while still meeting students' preferences for "practical" and enjoyable instruction, given the current educational environment where student reactions are granted considerably more weight than in the past (O'Brien, Rousseau, Goodman, \& DePalma, 2010; Trank \& Rynes, 2003). At present, there is a surprising lack of hard evidence about specific teaching practices that might help (e.g., Argyris, 2004; Green, 2010), although a number of ideas have been offered (e.g., L. Burke \& Rau, 2010; Rousseau \& McCarthy, 2007) that merit future empirical scrutiny.

\section{CONCLUSION}

We examined more than 800 syllabi for required management courses in MBA programs around the United States, representing the majority of such courses. Although these syllabi almost never explicitly mentioned EBM as a movement, a sizable minority included language suggesting the importance of research evidence for management practice. Our examination of differences at the instructor, course, and institution levels suggests that research findings are emphasized more by $\mathrm{PhD}$ holding instructors teaching $\mathrm{OB}$ or $\mathrm{HR}$ in more highly ranked MBA programs. These findings suggest that diffusion of the EBM concept may be following a path suggested by the diffusion of innovation, social network, and institutional theory literatures, although we encourage future research that more directly examines this possibility. Future research is also encouraged on the best ways to teach evidence-based management principles 
and practices such that students both learn the material and value that learning. While the research presented here is somewhat encouraging in regard to the current state of EBM in U.S. MBA programs (particularly in OB and HRM), continued work is needed from both research and teaching perspectives.

\section{REFERENCES}

AACSB International. 2007. Impact of research task force report. Association to Advance Collegiate Schools of Business: Tampa, FL. Retrieved March 6, 2010 from http://www. aacsb.edu/Resource_Centers/Research/Final/Impact_of_ Research_Report-FINAL.PDF.

American Association of University Professors. 2007. Trends in faculty status, 1975-2007. Retrieved on-line March 11, 2010 at http://www.ađup.org.

APA Task Force on Evidence-Based Practice. 2006. Evidencebased practice in psychology. American Psychologist, 61: 271-283.

Argyris, C. 2004. Reasons and rationalizations: The limits to organizations knowledge. New York: Oxford.

Augier, M. 2006. Making management matter: An interview with John Reed. Academy of Management Learning \& Education, 5: $84-100$.

Ayres, I. 2008. Super crunchers: Why thinking-by-numbers is the new way to be smart. New York: Bantam Books.

Bennis, W. G., \& O'Toole, J. May 2005. How business schools lost their way. Harvard Business Review, 83(5): 96-104.

Biglan, A. 1973. The characteristics of subject matter in different scientific areas. Journal of Applied Psychology, 57(3): 195203.

Blood, M. R. 1994. The role of organizational behavior in the business school curriculum. In J. Greenberg (Ed.), Organizational behavior: The state of the science: 207-220. Hillsdale, NJ: Erlbaum.

Brown, J. S., \& Duguid, P. 2002. Local knowledge: Innovation in the networked age. Management Learning, 33(4): 427-437.

Broughton, P. D. 2009. Harvard's masters of the apocalypse. London Times. Retrieved online April 1, 2010 at http://www. timesonline.co.uk/tol/news/uk/education/article5821706.ece.

Bureau of Labor Statistics, U.S. Department of Labor. 2010. Teachers-Postsecondary. Occupational Outlook Handbook, 2010-11 Edition. Retrieved online March 11, 2010 at http://www.bls.gov/oco.

Burke, L. A., \& Moore, J. E. 2003. A perennial dilemma in OB education: Engaging the traditional student. Academy of Management Learning \& Education, 2(1): 37-52.

Burke, L. A., \& Rau, B. 2010. The research-teaching gap in management. Academy of Management Learning \& Education, 9: 132-143.

Burke, M. J., Drasgow, F., \& Edwards, J. E. 2004. Closing sciencepractice knowledge gaps: Contributions of psychological research to human resource management. Human Resource Management, 43: 299-304.

Cohen, D. J. 2007. The very separate worlds of academic and practitioner publications in human resource management:
Reasons for the divide and concrete solutions for bridging the gap. Academy of Management Journal, 50: 1013-1019.

Cole, S. 1983. The hierarchy of the sciences? American Journal of Sociology, 89: 111-139.

Deadrick, D. L., \& Gibson, P. A. 2009. Revisiting the researchpractice gap in HR: A longitudinal analysis. Human Resource Management Review, 19: 144-153.

Deci, E. L., Koestner, R., \& Ryan, R. M. 1999. A meta-analytic review of experiments examining the effects of extrinsic rewards on intrinsic motivation. Psychological Bulletin, 25: 627-668.

DiMaggio, P., \& Powell, W. 1983. The iron cage revisited: Institutional isomorphism and collective rationality in organizational fields. American Sociological Review, 48: 147-160.

Eisenberger, R., \& Cameron, J. 1996. Detrimental effects of rewards: Reality or myth? American Psychologist: 51: 11531166.

Fernandes-Alles, M., \& Ramos-Rodriguez, A. 2009. Intellectual structure of human resources management research: $\bar{A}$ bibliometric analysis of the journal Human Resource Management, 1985-2005. Journal of the American Society for Information Science \& Technology, 60: 161-175.

Ford, K. 2005. Brands laid bare: Using market research for evidence-based brand management. Chichester, UK: Wiley \& Sons.

Fox, K. J., \& Milbourne, R. 1999. What determines research output of academic economists? Economic Record, 75(230): 256-267.

Gerhart, B., \& Rynes, S. L. 2003. Compensation: Theory, evidence, and strategic implications. Thousand Oaks, CA: Sage.

Glick, W. H., Miller, C. C., \& Cardinal, L. B. 2007. Making a life in the field of organization science. Journal of Organizational Behavior, 28: 817-835.

Gladwell, M. 2005. Blink: The power of thinking without thinking. New York: Little, Brown.

Goleman, D. 1995. Emotional intelligence: Why it can matter more than IQ. New York: Bantam Books.

Goodman, J. S., \& O'Brien, J. 2010. Teaching and learning using evidence-based principles. Draft manuscript.

Granovetter, M. 1973. The strength of weak ties. American Journal of Sociology, 81: 1287-1303.

Green, E. 2010, March 2. Building a better teacher. New York Times, http://www.nytimes.com/2010/03/07/magazine/ 07Teachers-t.html?em.

Halloun, I. A., \& Hestenes, D. 1985. Common sense concepts about motion. American Journal of Physics, 53: 1056-1065.

Hambrick, D. 1994. What if the academy actually mattered? Academy of Management Review, 19: 11-16.

Hambrick, D. C. 2004. The disintegration of strategic management: It's time to consolidate our gains. Strategic Organization, 2: 91-98.

Hambrick, D. C., \& Chen, M.-J. 2008. New academic fields as admittance-seeking social movements: The case of strategic management. Academy of Management Review, 33: 32-54.

Highhouse, S. A. 2008. Stubborn reliance on intuition and subjectivity in employee selection. Industrial and Organizational Psychology: Perspectives on Science and Practice, 1: 333-342. 
Hutchins, L. A., \& Burke, L. 2007. Identifying trainers' knowledge of training transfer research findings-Closing the gap between research and practice. International Journal of Training and Development, 11: 236-267.

Johns, G. 1993. Constraints on the adoption of psychology-based personnel practices: Lessons from organizational innovation. Personnel Psychology, 46: 569-592.

Kahan, D. M., \& Braman, D. 2006. Cultural cognition and public policy. Yale Law and Public Policy Review, 24: 147-170.

Kahan, D. M., Jenkins-Smith, H., \& Braman, D. 2010. Cultural cognition of scientific consensus. Yale Law School, Public Law Working Paper No. 205.

Khurana, R. 2007. From higher aims to hired hands: The social transformation of American business schools and unfulfilled promise of management as a profession. Princeton, NJ: Princeton University Press.

Kirkman, B. L., \& Law, K. 2005. International management research at AMJ: Our past, present, and future. Academy of Management Journal, 48: 377-386.

Latham, G. P. 2007. A speculative perspective on the transfer of behavioral science findings to the workplace: The times they are a-changin'. Academy of Management Journal, 50: 1027-1032.

Latham, G. P. 2009. Becoming the evidence-based manager. Boston: Davies-Black.

Latham, G. P., \& Latham, S. D. 2003. Facilitators and inhibitors of the transfer of knowledge between scientists and practitioners in human resource management: Leveraging cultural, individual, and institutional variables. European Journal of Work \& Organizational Psychology, 12: 245-256.

Latham, G. P., \& Stuart, H. C. 2007. Practicing what we preach: The practical significance of theories underlying HRL interventions for a MBA school. Human Resource Management Review, 17: 107-116.

Law, M. (Ed.). 2002. Evidence-based rehabilitation: $A$ guide to practice. Thorofore, NJ: SLACK Inc.

Leicht, K. T., \& Fennell, M. L. 2001. Professional work: A sociological approach. Malden, MA: Blackwell.

Lewis, M. 2004. Moneyball: The art of winning an unfair game. New York: W.W. Norton \& Company.

Locke, E. A. 2003. The Blackwell handbook of principles of organizational behavior. Wiley-Blackwell.

Locke, E. A. 2009. Handbook of principles of organizational behavior: Indispensible knowledge for evidence-based management, 2nd ed. New York: Wiley.

Locke, E. A., Feren, D. B., McCaleb, V. M., Shaw, K. N., \& Denny, D. T. 1980. The relative effectiveness of four methods of motivating employee performance. In K. D. Duncan, M. M. Gruenber, \& D. Wallis (Eds.), Changes in working life: 363388. New York: Wiley.

Maranto, C. L., \& Streuly, C. A. 1994. The determinants of accounting professors' publishing productivity-The early career. Contemporary Accounting Research, 10: 387-407.

Mintzberg, H. 2005. Managers not MBAs: A hard look at the soft practice of managing and management development. San Francisco: Berrett-Koehler.

Mitra, D., \& Golder, P. N. 2009. Does academic research help or hurt MBA programs? Journal of Marketing, 72 (September 2008): 31-49.
Navarro, P. 2008. The MBA core curricula of top-ranked U.S. business schools: A study in failure? Academy of Management Learning \& Education, 7: 108-123.

O'Brien, J., Rousseau, D., Goodman, J., \& DePalma, J. 2010. Blood, sweat, and fears: The ground truth of teaching evidencebased management. Working paper, version 2.0.

Paulos, J. A. 2001. Innumeracy: Mathematical illiteracy and its consequences. New York: Hill \& Wang.

Pearce, J. L. 2003. President's message: A bifurcated academy. Academy of Management Newsletter, March: 1-2.

Pearce, J. L. 2009. Organizational behavior: Real research for real managers. Irvine, CA: Melvin \& Leigh.

Pfeffer, J. 1993. Barriers to the advance of organizational science: Paradigm development as a dependent variable. Academy of Management Review, 18: 599-620.

Pfeffer, J. 1998. Six dangerous myths about pay. Harvard Business Review, 76: 108-120.

Pfeffer, J., \& Sutton, R. I. 2000. The knowing-doing gap: How smart companies turn knowledge into action. Boston: Harvard Business School Press.

Pfeffer, J., \& Sutton, R. I. 2006. Hard facts, dangerous half-truths, and total nonsense: Profiting from evidence-based management. Cambridge: Harvard Business School Press.

Pfeffer, J., \& Sutton, R. I. 2007. Evidence-based management. Harvard Business Review, 84(4): 62-74.

Pindyck, R. S., \& Rubinfeld, D. L. 1981. Econometric models and forecasts, 2nd ed. New York: McGraw-Hill.

Pink, D. H. 2009. Drive: The surprising truth about what motivates us. New York: Riverhead.

Rogers, E. M. 1995. Lessons for guidelines from the diffusion of innovations. Joint Commission Journal on Quality Improvement, 21(7): 324-328.

Rogers, E. M. 2003. Diffusion of innovations. New York: Free Press.

Rousseau, D. M. 2006. Is there such a thing as evidence-based management? Academy of Management Review, 31: 256269.

Rousseau, D. M., \& McCarthy, S. 2007. Educating managers from an evidence-based perspective. Academy of Management Learning \& Education, 6: 84-101.

Rubin, R. S., \& Dierdorff, E. C. 2009. How relevant is the MBA? Assessing the alignment of required curricula and required management competencies. Academy of Management Learning \& Education, 8: 208-224.

Rynes, S. L., Bartunek, J. M., \& Daft, R. L. 2001. Across the great divide: Knowledge creation and transfer between practitioners and academics. Academy of Management Journal, 44: 340-355.

Rynes, S. L., Colbert, A. E., \& Brown, K. G. 2002. HR professionals' beliefs about effective human resource practices: Correspondence between research and practice. Human Resource Management, 41: 149-174.

Rynes, S. L., Giluk, T. L., \& Brown, K. G. 2007. The very separate worlds of academic and practitioner publications in human resource management: Implications for evidence-based management. Academy of Management Journal, 50: 9871008.

Schmidt, F. L., \& Hunter, J. E. 1998. The validity and utility of selection methods in personnel psychology: Practical and 
theoretical implications of 85 years of research findings. Psychological Bulletin, 124: 262-274.

Southworth, G., \& Conner, C. 1999. Managing improving primary schools: Using evidence-based management. Oxford, UK: Routledge.

Specter, M. 2009. Denialism: How irrational thinking hinders scientific progress, harms the planet, and threatens our lives. New York: Penguin Press.

Steiner, J. F., Lanphear, B. P., Curtis, P., \& Vu, K. O. 2002. Indicators of early research productivity among primary care fellows. Journal of General Internal Medicine, 17: 854-860.

Straus, S. E., Richardson, W. S., Glasziou, P., \& Haynes, R. B. 2005. Evidence based medicine: How to practice and teach EBM, 3rd ed. Edinburgh: Elsevier.

Tranfield, D., Denyer, D., \& Smart, P. 2003. Towards a method- ology for developing evidence-informed management knowledge by means of systematic review. British Journal of Management, 14: 207-222.

Trank, C. Q., \& Rynes, S. L. 2003. Who moved our cheese? Reclaiming professionalism in business education. Academy of Management Learning \& Education, 2: 189-205.

U.S. Department of Education, National Center for Education Statistics. 2009. Digest of Education Statistics, 2008 (NCES 2009-020), Chapter 3.

Warren Piper, D., Nulty, D. D., \& O'Grady, G. 1996. Examination practices and procedures in Australian universities. Canberra: Department of Employment, Education, Training and Youth Affairs.

Wenger, E., McDermott, R., \& Snyder, W. M. 2002. Cultivating communities of practice. Cambridge: Cambridge University Press.

Steven D. Charlier is a doctoral candidate in the Management \& Organizations department at the University of Iowa. He received his master's degree in international management from the University of Denver. His research interests include leadership in virtual teams, e-learning, and bridging the academic-practitioner gap.

Kenneth G. Brown is a Henry B. Tippie Research Fellow and associate professor of Management and Organizations at the University of Iowa. He received his PhD from Michigan State University and is certified as a senior professional in human resource management. Brown's research focuses on motivation, learning, and training evaluation.

Sara L. Rynes (PhD, University of Wisconsin) is the John F. Murray Professor of Management and Organizations at the University of Iowa. Her research and teaching interests include strategic human resource management, academic-practitioner relationships, management scholarship of teaching and learning, staffing, compensation, and sustainability. 
Copyright of Academy of Management Learning \& Education is the property of Academy of Management and its content may not be copied or emailed to multiple sites or posted to a listserv without the copyright holder's express written permission. However, users may print, download, or email articles for individual use. 